\title{
AN OVARIAN STEROID CELL TUMOUR CAUSING VIRILISATION- A RARE CASE REPORT
}

N. Gopal ${ }^{1}$, Subbappa K², Shilpa shivanna B3 ${ }^{3}$ Prashanth Joshi ${ }^{4}$, Srividya 5 .

\section{HOW TO CITE THIS ARTICLE:}

N. Gopal, Subbappa K, Shilpa shivanna B, Prashanth Joshi, Srividya. "An ovarian steroid cell tumour causing virilisation- A rare case report". Journal of Evolution of Medical and Dental Sciences 2013; Vol2, Issue 28, July 15; Page: 5075-5080.

INTRODUCTION: Steroid cell tumor of the ovary a very rare androgen secreting tumor accounts for less than $0.1 \%$ of ovarian tumors. These tumors may present at any age ranging from 2 to 80 yrs \& associated with hormonal activity \& virilisation. These tumors are most commonly unilateral, may be both benign or malignant, most of these tumors are usually diagnosed in early stages because of virilisation caused by these tumors.

In an extensive literature search (medline \& pubmed) from 1979, only around 80 cases of ovarian steroid cell tumors have been reported. As ovarian stromal tumors are infrequent, little attention was given to their response to radiotherapy and chemotherapy. A recent report stated gonadotropin releasing hormone agonist was effective in treating steroid cell tumors.

Here we present the case of a rare ovarian steroid cell tumor in a 32 yrs old woman who presented with virilisation.

CASE REPORT: A 32 yrs old woman with P2L1D1A1 presented with history of amenorrhea of 7 months duration, hoarseness of voice since 6 yrs, decrease in breast size since 6 yrs, lower abdominal pain which is dull aching type, coarse hair growth over the body since 2 yrs. She attained menarche at the age of 12 yrs. Her previous menstrual cycles were normal.

Physical examination revealed male pattern of coarse hair distribution in the beard region, face, chest wall, abdomen, arms and thighs. Both breasts were small in size, no mass palpable per abdominally.

Local examination shows clitoromegaly. On per vaginal examination, there was right fornicis fullness, and a mass felt through the right fornix.

INVESTIGATIONS: Ultrasonography of abdominopelvic region revealed a solid right adnexal mass of $4.3 \times 4.3 \mathrm{~cm}$, Doppler study shows minimal vascularity in the tumor. CT scan revealed a right adnexal solid mass of $6.1 \times 4.3 \mathrm{~cm}$. No ascites.

PRE-OPERATIVE HORMONAL ASSAY:

\begin{tabular}{|l|l|l|}
\hline & VALUES & NORMAL \\
\hline S. Total Testosterone level & $197.14 \mathrm{ng} / \mathrm{dl}$ & $15-70 \mathrm{ng} / \mathrm{dl}$ \\
\hline S. Free Testosterone level & $79 \mathrm{ng} / \mathrm{dl}$ & $0.06-3.18 \mathrm{ng} / \mathrm{dl}$ \\
\hline $17-O H$ Progesterone & $5.67 \mathrm{ng} / \mathrm{dl}$ & $0.11-5 \mathrm{ng} / \mathrm{dl}$ \\
\hline DHEAS04 & $160 \mathrm{microgm} / \mathrm{dl}$ & $35-430 \mathrm{microgm} / \mathrm{dl}$ \\
\hline S. Prolactin level & $5.25 \mathrm{ng} / \mathrm{dl}$ & \\
\hline FSH & $2.42 \mathrm{mIU} / \mathrm{ml}$ & $1.9-12.5$ \\
\hline LH & $4.07 \mathrm{mIU} / \mathrm{ml}$ & $2.5-10.2$ \\
\hline
\end{tabular}


Intra-operatively, the right ovarian mass is about $6 \times 4 \mathrm{cms}$, tan brown, well encapsulated solid mass, firm in consistency. Left ovary is normal in size and appearance. Hysterectomy with bilateral salpingo-oophorectomy was done.

HISTOPATHOLOGICAL REPORT: Grossly the ovary was enlarged and measured 6.5 x 4 x $3.5 \mathrm{~cm}$, external surface was smooth. Cut surface showed a circumscribed, lobulated tumor which was yellow in colour.

Microscopy revealed a tumor composed of lobules of tumor cells arranged in sheets and nests. These cells were polyhedral and showed abundant clear to eosinophilic granular cytoplasm (Fig 2). No mitosis or necrosis was seen. The histopathological diagnosis was steroid cell tumor.

POST SURGICAL FOLLOW-UP OF THE PATIENT: Patient was followed regularly after surgery for 3 yrs.

\begin{tabular}{|c|c|c|c|c|c|}
\hline & $\begin{array}{l}\text { Free } \\
\text { testosterone } \\
\text { levels }\end{array}$ & $\begin{array}{l}\text { hair } \\
\text { distribution }\end{array}$ & Breast changes & clitoromegaly & $\begin{array}{l}\text { Recurrence of } \\
\text { the disease( BY } \\
\text { ULTRASOUND) }\end{array}$ \\
\hline $\begin{array}{lr}1^{\text {st }} \text { visit } \\
\text { after } & 2 \\
\text { months } & \end{array}$ & $0.45 \mathrm{ng} / \mathrm{dl}$ & $\begin{array}{l}\text { Coarse hair } \\
\text { became thin }\end{array}$ & $\begin{array}{l}\text { Mild enlargement in } \\
\text { the breast }\end{array}$ & No changes & No \\
\hline $\begin{array}{lr}2^{\text {nd }} & \text { visit } \\
\text { after } & 6 \\
\text { months } & \end{array}$ & $0.14 \mathrm{ng} / \mathrm{dl}$ & $\begin{array}{l}\text { Almost } \\
\text { feminine }\end{array}$ & $\begin{array}{l}\text { Mild to moderate } \\
\text { enlargement seen }\end{array}$ & No changes & No \\
\hline $\begin{array}{l}3^{\text {rd }} \quad \text { visit } \\
\text { after } 1 \mathrm{yr}\end{array}$ & $0.12 \mathrm{ng} / \mathrm{dl}$ & Feminine & Breasts enlarged & No changes & No \\
\hline 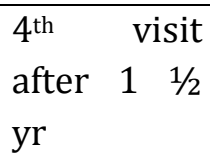 & $0.16 \mathrm{ng} / \mathrm{dl}$ & Feminine & $\begin{array}{l}\text { Enlarged almost to } \\
\text { normal size }\end{array}$ & No changes & No \\
\hline $\begin{array}{l}5^{\text {th }} \text { visit } \\
\text { after } 2 \text { yrs }\end{array}$ & $0.09 \mathrm{ng} / \mathrm{dl}$ & Feminine & $\begin{array}{l}\text { Enlarged almost to } \\
\text { normal size }\end{array}$ & No changes & No \\
\hline $\begin{array}{l}6^{\text {th }} \text { visit } \\
\text { after } 3 \text { yrs }\end{array}$ & $0.01 \mathrm{ng} / \mathrm{dl}$ & Feminine & $\begin{array}{l}\text { Enlarged to normal } \\
\text { size }\end{array}$ & No changes & $\begin{array}{lr}\text { CT scan } & \text { study } \\
\text { shows } & \text { no } \\
\text { recurrence } & \end{array}$ \\
\hline
\end{tabular}

DISCUSSION: Ovarian steroid cell tumor, a rare tumor accounts $<0.1 \%$ of all ovarian tumors. They are usually benign, unilateral and characterised by steroid cell proliferation.

This term was first described by Scully. Prior to this, it was called as lipoid cell tumor. Majority of these tumors are benign, about $20 \%$ of patients developed metastatic lesions within the peritoneal cavity. Heyes and Scully identified pathologic features that are highly associated with malignancy - more than 2 mitoses per high power field, necrosis, size of $7 \mathrm{cms}$ or larger and grade 2 or 3 nuclear atypia.

The primary treatment is surgery. Surgical treatment using total abdominal hysterectomy with bilateral salpingo-oophorectomy and complete surgical staging is appropriate management for 
older women, who are not willing to preserve their fertility. However such practices require mandatory follow-up and evaluation.

In virilised patient, serum testosterone levels more than $2 \mathrm{ng} / \mathrm{dl}$, normal DHEA-S and no evidence of 21 alfa hydroxylase deficiency are strong indicators of steroid cell tumor of ovary, as in our case.

CONCLUSION: Steroid cell tumors of the ovary are rare tumors, more commonly benign with virilising property with distressing symptoms to the patient because of abnormal pattern of hair distribution, voice changes. One has to be aware of this condition in women who present with above symptoms, so that one can prevent the spread of tumors, unwanted signs and symptoms like hair growth, voice changes, \& clitoromegaly.

\section{REFERENCES:}

1. Scully RE. Atlas of Tumor Pathology. 2nd ed. Washington, DC: Armed Forces Institute of Pathology; 1979. Tumors of the ovary and maldeveloped gonads, fallopian tube, and broad ligament; pp. 215-220.

2. Hayes MC, Scully RE. Ovarian steroid cell tumors (not otherwise specified) Am J Surg Pathol.1987; 11:835-845. [PubMed]

3. Hartman LC, Young RH, Evans MP, Podratz KC. Ovarian sex cord-stromal tumors. In: Hoskins WJ, Perez CA, Young RC, editors. Principles and Practice of Gynecologic Oncology. 2nd ed. Philadelphia: Lippincott-Raven; 1997. pp. 1015-1019.

4. Wang PH, Chao HT, Lee RC, Lai CR, Lee WL, Kwok CF, et al. Steroid cell tumors of the ovary: clinical, ultrasonic, and MRI diagnosis--a case report. Eur J Radiol. 1998; 26:269-273. [PubMed]

5. Outwater EK, Marchetto B, Wagner BJ. Virilizing tumors of the ovary: imaging features. Ultrasound Obstet Gynecol. 2000; 15:365-371. [PubMed]

6. Tayler HB, Norris HJ. Lipoid cell tumors of the ovary. Cancer. 1967; 20:1953-1962. [PubMed]

7. Donovan JT, Otis CN, Powell JL, Cathcart HK. Cushing's syndrome secondary to malignant lipoid cell tumor of the ovary. Gynecol Oncol. 1993; 50:249-253. [PubMed]

8. Brewer CA, Shevlin D. Encouraging response of an advanced steroid-cell tumor to GnRH agonist therapy. Obstet Gynecol. 1998; 92(4 Pt 2):661-663. [PubMed]

9. Wang PH, Chao HT, Lee WL. Use of a long-acting gonadotropin-releasing hormone agonist for treatment of steroid cell tumors of the ovary. Fertil Steril. 1998; 69:353-355. [PubMed]

10. Sassone AM, Timor-Tritsch IE, Artner A, Westhoff C, Warren WB. Transvaginal sonographic characterization of ovarian disease: evaluation of a new scoring system to predict ovarian malignancy. Obstet Gynecol. 1991; 78:70-76. [PubMed]

11. Reedy MB, Richards WE, Ueland F, Uy K, Lee EY, Bryant C, et al. Ovarian steroid cell tumors, not otherwise specified: a case report and literature review. Gynecol Oncol. 1999; 75:293297. [PubMed]

12. Luk WT, Lee N, Chang TC, Chu KK. Lipid cell tumor of the ovary associated with endometrial adenocarcinoma-a case report. Changgeng Yi Xue Za Zhi. 1989; 12:244-248. [PubMed]

13. Elhadd TA, Connolly V, Cruickshank D, Kelly WF. An ovarian lipid cell tumour causing virilization and Cushing's syndrome. Clin Endocrinol (Oxf) 1996; 44:723-725. [PubMed] 


\section{CASE REPORT}
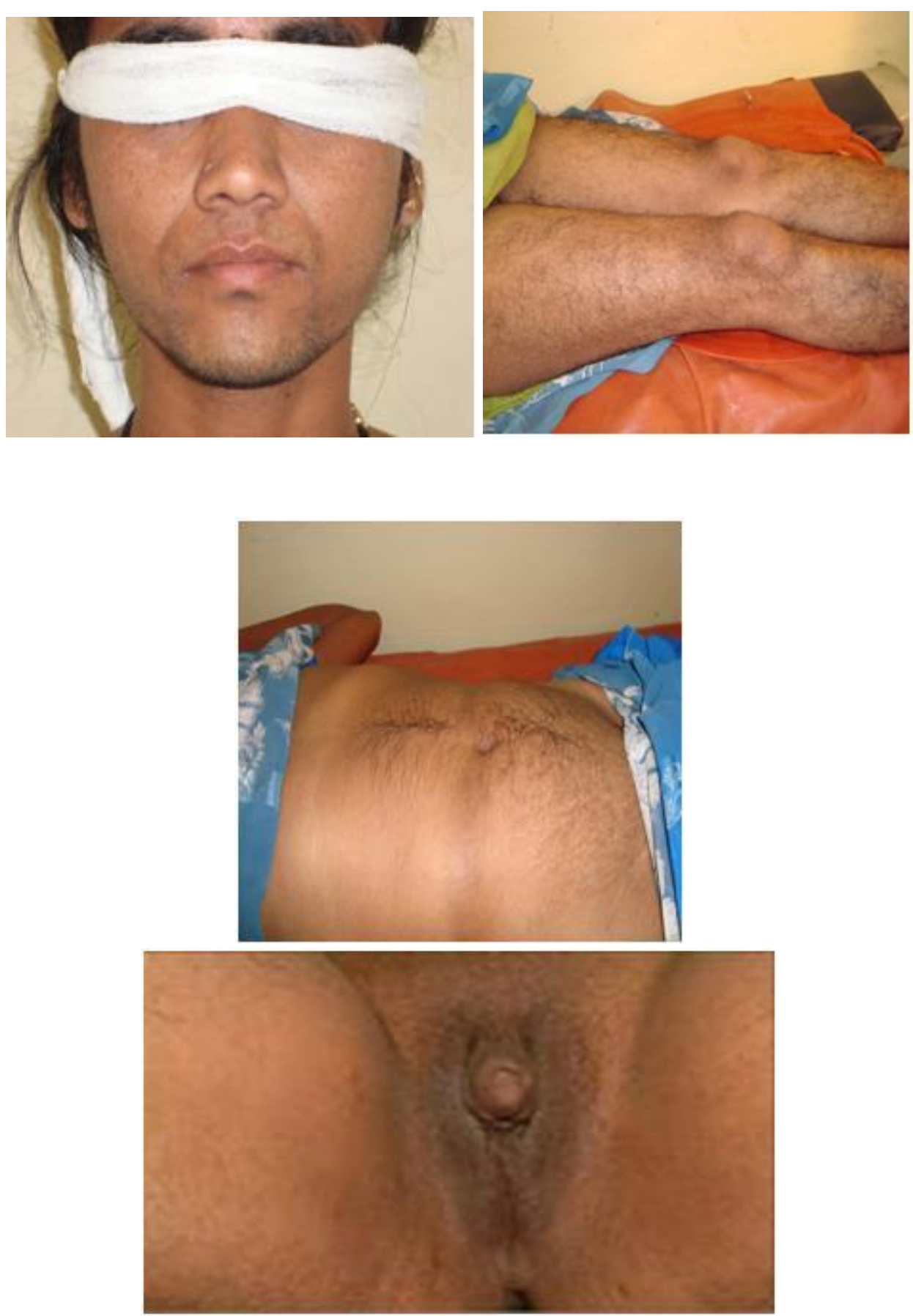


\section{CASE REPORT}

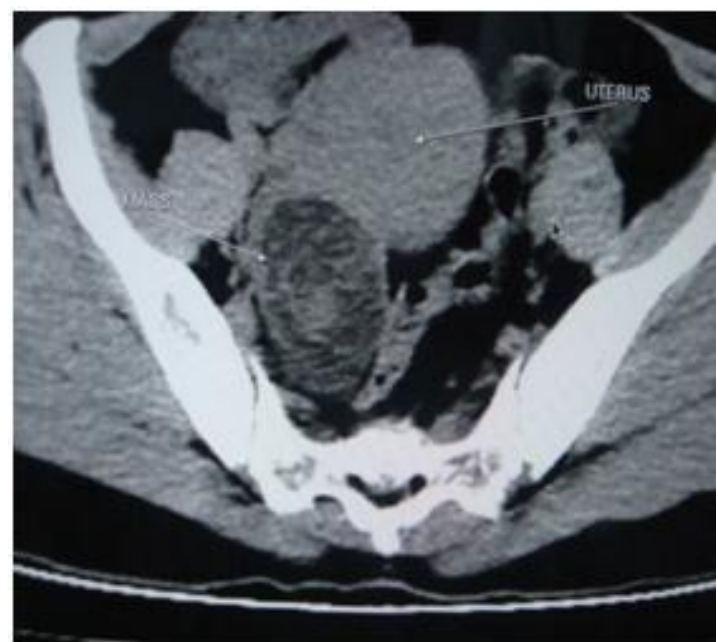

\section{CT SCAN IMAGE}
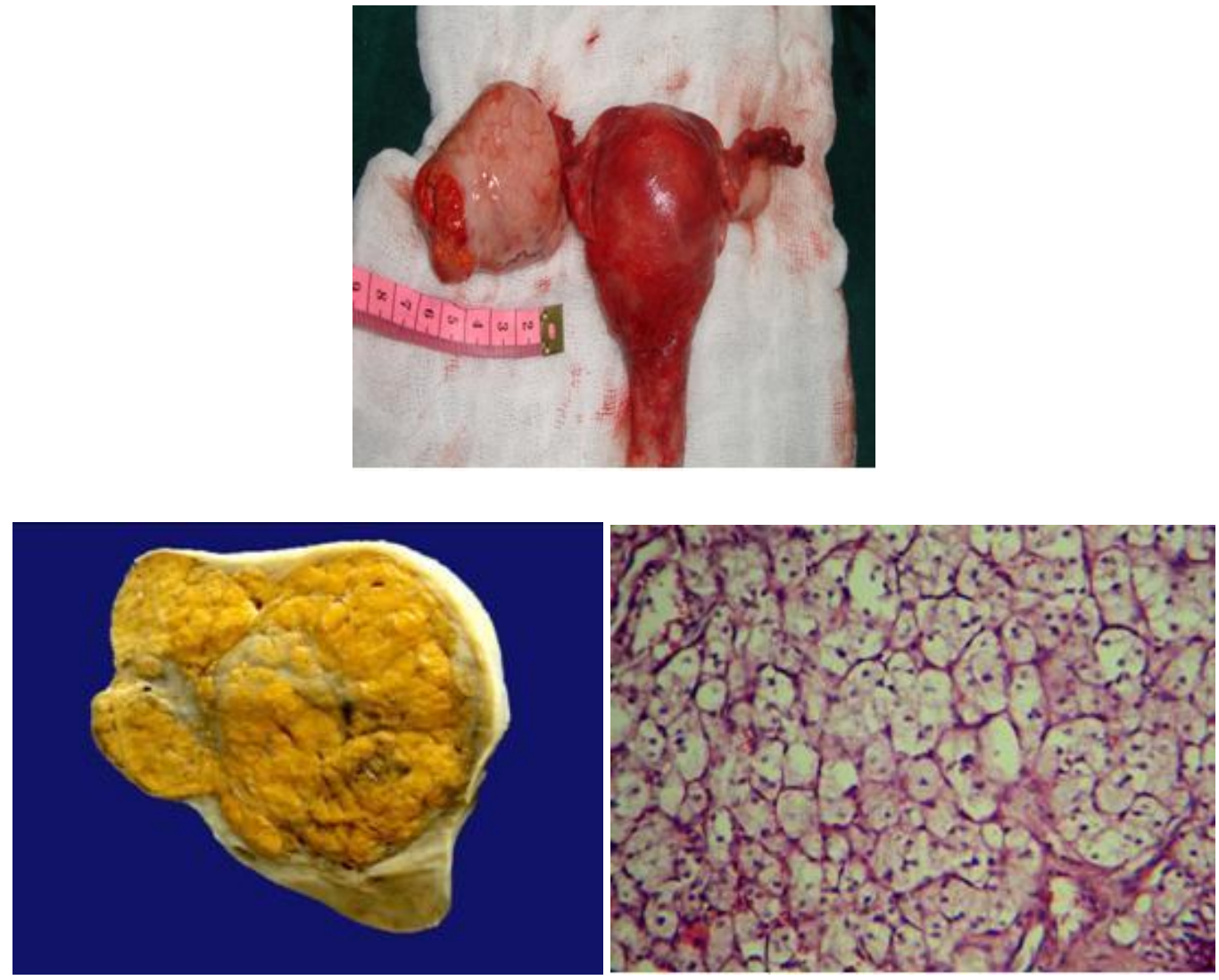

Fig 1: Gross appearance of Steroid cell tumor. Cut section of the ovary showing a yellow lobulated, circumscribed tumor.

Fig 2: Microphotograph showing polyhedral cells with clear to eosinophilic granular cytoplasm (H\&E x 400). 


\section{CASE REPORT}

Images taken after surgery:
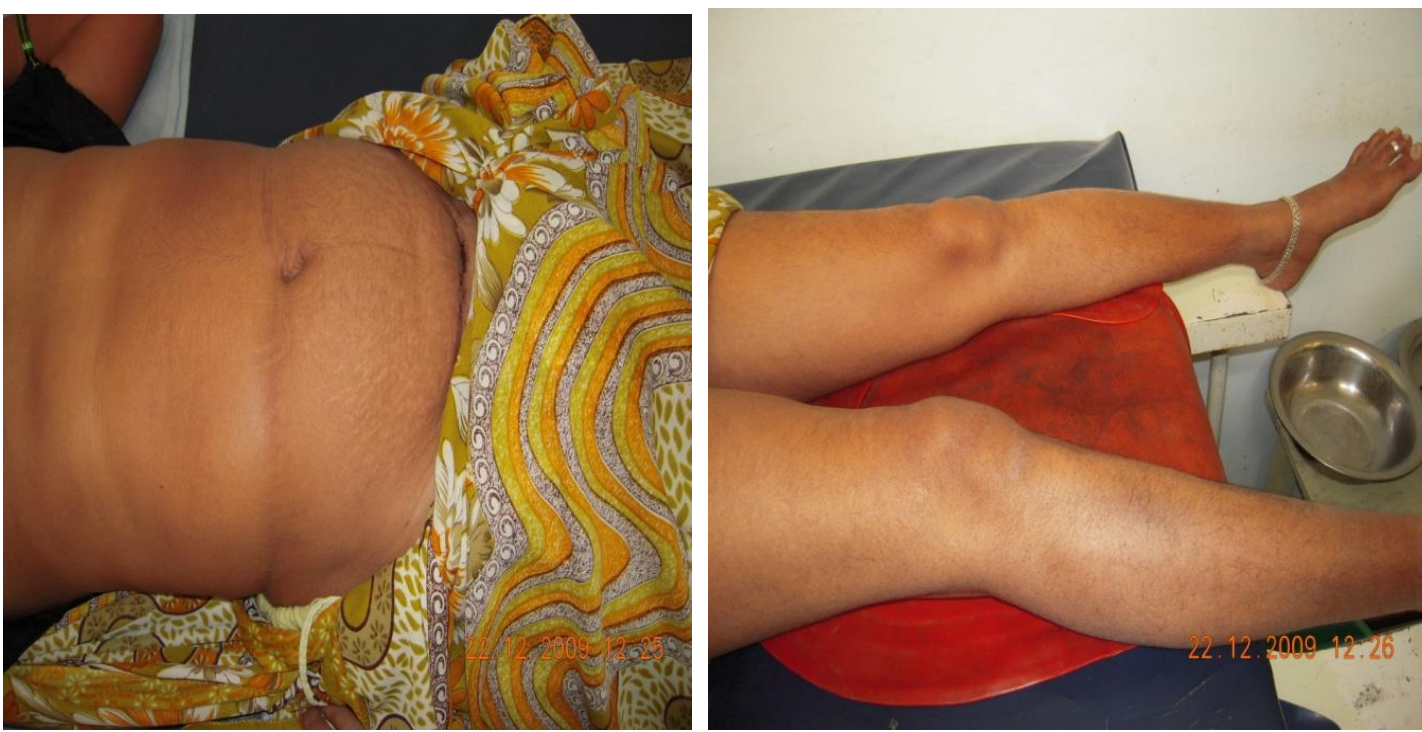

\section{AUTHORS}

1. N Gopal

2. Subbappa K

3. Shilpashivanna B

4. Prashanth joshi

5. Srividya

\section{PARTICULARS OF CONTRIBUTORS:}

1. Professor, Department of OBG, Adhichunchanagiri institute of medical Sciences (aims).

2. Senior resident, Department of OBG, Adhichunchanagiri institute of medical Sciences (aims).

3. Associate Professor, Department of OBG, Adhichunchanagiri institute of Medical Sciences (aims).

4. Associate Professor, Department of OBG, Adhichunchanagiri institute of Medical Sciences (aims). 